\title{
PENINGKATAN PRODUKTIVITAS KELOMPOK USAHA DESAIN INTERIOR MELALUI PROSES PRODUKSI BERBASIS ECO-DESIGN DI KOTA KENDARI
}

\author{
Asri Andrias(1), Siti Belinda Amri(2), Aspin(3) \\ Jurusan Arsitektur, Universitas Halu Oleo 1),2),3), 4) \\ Email: linda.amri@gmail.com 2)
}

\begin{abstract}
Discourse on green construction and sustainable development is currently a major topic in everywhere, including Indonesia. In every production activities, the manufacturing process always produces waste or residual production. In connection with the issue of sustainable development, certainly, the problem of waste utilization that frequently occur in the industrial sector should be minimized and handled so that no adverse impact to the environment. The interior design enterprise is one of the creative industries which is mostly using wood as a raw materials, waste generated from this manufacturing is not in small amount. The community service was collaborated with two interior design enterprises, namely CV Abstrak $3 D$ and CV Garis Pratama, both located in Kendari and classified as a small enterprises. The main activity wasto given assistance on the production processbased eco-design, which is a production process that applies the principles of environmentally friendly in every process. Environmentally friendly starting from the identification phase, production, waste processing, until the marketing phase. Through this community service, an increase in productivity as well as knowledge were achieved by both of partners. One of examples of productivity improvement is the ability of the enterprises to process production waste into some valuable goods
\end{abstract}

Keywords: creative industry, interior design, furniture, eco-design, wood waste utilization 


\section{PENDAHULUAN}

Menurut Departemen Perdagangan Indonesia (2007), industri kreatif dididefinisikan sebagai "industri yang berasal dari pemanfaatan kreativitas, keterampilan serta bakat individu untuk menciptakan kesejahteraan serta lapangan pekerjaan dengan menghasilkan dan engeksploitasi daya kreasi dan daya cipta individu tersebut". Industri kreatif bermodalkan ide-ide kreatif, talenta dan keterampilan yang berasal dari sumber daya manusia sebagai penciptanya. Industri kreatif berkaitan erat dengan bidang desain, salah satunya yaitu desain interior. Lewat usaha jasa desain interior, pelaku usaha ini dapat menyalurkan ide, kreativitas dan berbagai inspirasi unik untuk menata sebuah objek dalam ruangan sehingga terlihat lebih menarik dan menciptakan rasa nyaman kepada penghuninya.

Usaha jasa desain interior tidak hanya melayani jasa gambar tetapi juga menghasilkan furniture untuk ruangan. Adanya jasa desain interior, memudahkan masyarakat dalam menata ruangan dan mewujudkan keinginan mereka terhadap desain ruangan itu sendiri. Sebab, rancangan interior ruangan yang mereka inginkan termasuk perlengkapan perabotnya dapat terpenuhi lewat jasa desain interior sekaligus dibantu dalam penataannya.

Keberadaan industri kreatif berupa usaha desain interior di Kota Kendari mengalami kemajuan pesat selama 3 tahun terakhir. Produk-produk interior yang berbahan dasar kayu solid maupun multipleks menjadi pilihan bagi masyarakat yang ingin memiliki perabotan pelengkap di dalam rumah. Perkembangan teknologi informasi telah memberikan masyarakat berbagai macam pilihan bagi produk interiornya, dari yang dahulu hanya berupa produk kayu solid, kini telah dibarengi dengan hadirnya furniture merbahan dasar kayu olahan. hal ini tentunya memberi peluang bagi kelompok-kelompok usaha yang ingin mengembangkan usahanya.

Usaha yang menjadi mitra terdiri atas 2 (dua) yakni Usaha Interior Abstrak 3D dan Garis Pratama. Usaha Abstrak 3D maupun Garis Pratama merupakan usaha yang bergerak dalam pengadaan furniture dan desain interior. Kedua mitra usaha ini sama-sama dijalankan secara mandiri oleh sekelompok pemuda. Abstrak 3D, memiliki anggota dan tenaga kerja sebanyak 7 orang, sedangkan Garis Pratama terdiri atas 6 orang. Setiap bulannya kedua usaha ini mampu menyuplai beberapa furniture maupun melakukan pekerjaan desain interior untuk sejumlah rumah tinggal, kantor, dan ruko. Sistem pemasaran yang diterapkan keduanya adalah by order, yakni produksi dijalankan jika ada permintaan dari konsumen. Dengan banyaknya pesanan produk tentu saja mengakibatkan meningkatnya produksi.

Keberadaan usaha desain produk furniture dan interior ini sama halnya dengan usaha lainnya yang bergerak di bidang produksi bahan baku menjadi bahan siap pakai tentunya memiliki permasalahan yakni limbah produksi. Khusus untuk jenis usaha ini, limbah yang dihasilkan sebagian besar berupa potongan-potongan kayu baik kayu solid maupun multipleks dan pelapis luar/finishing berupa tacon sheet, HPL dan lain sebagainya. Keberadaan limbah ini menjadi permasalahan tersendiri. Sampah-sampah hasil olahan ini biasanya dibuang begitu saja ataupun dibakar.

Telah banyak peraturan pemerintah yang mengatur tentang bagaimana penanganan limbah industri, selain itu pemerintah mewacanakan "zero waste" pada sektor industri. Pada dasarnya "zero waste" atau produksi tanpa limbah sangat susah diterapkan, sehingga yang tepat adalah mengurangi jumlah limbah yang dihasilkan. Banyak cara yang bisa dilakukan, diantaranya produksi berbasis ecodesign atau ramah terhadap lingkungan dengan menerapkan prinsip 3R (reduce, reuse, dan recycle).

Masalah yang muncul di masyarakat adalah kurangnya kesadaran akan pola hidup ramah lingkungan. Sedangkan di bidang usaha interior/furniture masih banyak usaha yang belum ramah lingkungan baik dalam proses pemanfaatan bahan baku, maupun pengelolaan limbah. Adapun limbah produksi yang dihasilkan umumnya berupa serbuk kayu dan potongan multipleks. Belum ada penanganan secara khusus terhadap limbah tersebut, sebagian besar masih secara konvensional yakni dibakar. Sehingga yang harus ditemukan adalah bagaimana limbah produksi tersebut dapat dikurangi dan dimanfaatkan sehingga menjadi produk baru yang selain bermanfaat bagi lingkungan juga mampu meningkatkan pendapatan kelompok usaha tersebut. 


\section{KAJIAN PUSTAKA}

Berdasarkan Undang-Undang Pokok Lingkungan Hidup (UUPLH) RI No. 23 Tahun 1997, yang dimaksud dengan limbah adalah sisa atau usaha dan/atau kegiatan. Sementara itu pengertian limbah kayu adalah kayu sisa potongan dalam berbagai bentuk dan ukuran yang terpaksa harus dikorbankan dalam proses produksinya karena tidak dapat menghasilkan produk (output) yang bernilai tinggi dari segi ekonomi dengan tingkat teknologi pengolahan tertentu (DEPTAN, 1970). Sementara itu sejalan dengan pengertian tersebut, Sunarso dan Simarmarta (1980) dalam Iriawan (1993) dan Samsul Bahri (2013) menjelaskan bahwa limbah kayu adalah sisa-sia kayu atau bagian kayu yang dianggap tidak bernilai ekonomi lagi dalam proses tertentu, pada waktu tertentu dan tempat tertentu yang mungkin masih dimanfaatkan pada proses dan waktu yang berbeda.

Selain dari limbah yang berasal dari kayu, limbah dari usaha ini juga ada yang berupa:

1. Limbah bahan finishing ( contohnya sisa veneer, melamin, tacon sheet, dan HPL) beserta peralatan bantu lainnya

2. Limbah kimia sekunder sebagai hasil dari alat bantu dari sebuah industri kayu misal: accu dari mesin forklift, oli/pelumas bekas, lampu bekas, tinta dan lain-lain. Limbah ini belum begitu besar volumenya akan tetapi masih belum terkoordinasi dengan baik.

3. Bahan pembantu lain seperti kardus, plastik pembungkus, kertas amplas bekas, kain bekas untuk proses finishing, pisau bekas dari mesin serut dan lainnya.

Eco-design adalah suatu konsep pembuatan produk yang bertujuan untuk meminimalis ir dampak langsung atau tidak langsung yang dihasilkan oleh suatu produk selama siklus hidupnya, sebisa mungkin tujuan utamanya adalah mendesain suatu produk yang ramah lingkungan. Hal ini termasuk mempertimbangkan dampak lingkungan suatu produk, desain serta proses yang ditempuh dalam menciptakan produk. (Lewis; Gertsakis, 2001 dalam Garcia, Filho, 2008).

Lebih lanjut, terdapat 4 tipe eco-design (Rathenau Institute, 2001 dalam Garcia, Filho, 2008), yakni: pengembangan produk; re-desain produk; inovasi fungsi; inovasi system. Selain itu menurut Wentz dalam Petunjuk Teknik PenangananLimbah Lingkungan Hidup (2012), pengelolaan limbah industri meliputi aspekaspek yang berhubungan dengan:

1. Eliminasi atau reduksi limbah

2. Recycling/reuse limbah

3. Pengolahan/destruksi limbah

4. Pembuangan limbah.

Lebih lanjut dikatakan bahwa tahapan awal dari pengelolaan limbah adalah pemisahan limbah berdasarkan jenis dan ukurannya, hal ini penting dilakukan untuk memastikan seberapa banyak sisa produksi yang masih dapat digunakan yang tidak bisa. Aspek pertama adalah eliminasi atau reduksi (atau dikenal juga sebagai minimisasi) limbah sebenarnya merupakan konsep yang relatif "baru", karena dikembangkan setelah pengelolaan limbah industri mengalami penyempurnaan beberapa kali. Mengurangi (reduce) potensi limbah dari proses produksi dapat dilakukan dengan melakukan perencanaan dan desain yang tepat pada produk interior dan furniture yang dibuat. Proses pemotongan bahan baku juga harus dilakukan dengan cermat untuk mengurangi kesalahan yang berakibat pada timbulnya limbah.

Aspek kedua adalah recycling/reuse limbah. Memanfaatkankembali limbah menjadi sesuatu yang bermanfaat. Beberapa industri memanfaatkan kembali bahan baku yang masih dapat dimanfaatkan. Salah stau pemanfaatannya adalah dengan membuat barang-barang kerajinan ataupun produk interior lain, hal ini berlaku pada sisa produksi berupa potonganpotongan kayu. Keberadaan kerajinan dengan berbahan baku limbah kayu ini mempunyai keuntungan berganda, yaitu disatu sisi terdapat kemudahan dalam mendapatkan bahan baku.

Destruksi atau proses pemusnahan sampah/limbah kerap terjadi di industri. Kondisi yang terjadi pada umumnya ialah dengan cara dibakar. Hal ini pada dasarnya berdampak kurang bagi lingkungan, karena proses pembakaran berarti melepaskan $\mathrm{CO} 2 \mathrm{ke}$ udara. Tahapan selanjutnya adalah pembuangan limbah. Kedua tahapan ini merupakan jalan terakhir jika kedua proses selanjutnya tidak dapat dilakukan, akan tetapi perlu pengawasan dan kesadaran untuk meminimalkan dampak terhadap lingkungan.

\section{METODE}

Metode pendekatan yang diterapkan dalam kegiatan ini meliputi pendekatan partisipatif, 
pendekatan kelompok, pendekatan individual, metode ceramah, metode diskusi/FGD. Pendekatan partisipatif digunakan agar mitra ikut berpartisipasi secara aktif terhadap semua kegiatan mulai dari awal sampai akhir.

Rencana kegiatan pengabdian dibagi menjadi tiga tahap, yaitu kegiatan pelatihan eco-design dalam proses produksi, kegiatan pengembangan produk dari limbah produksi, dan kegiatan perluasan pemasaran produk.

1. Rencana kegiatan pelatihan eco-design, meliputi:

a. Identifikasi dan monitoring proses produksi utama, yaitu meliputi teknik pemotongan dan pengolahan bahan baku hingga pembuangan limbah. Identifikasi ini guna menerapkan prinsip reduce, teknik produksi yang mengurangi timbulan limbah.

b. Menyusun materi mengenai eco-design dalam usaha produksi desain interior melalu modul.

c. Melaksanakan pelatihan produksi elemen interior berbasis eco-design kepada KUB Mitra, meliputi pengetahuan dasar produksi hingga tahapan manajemen pemasaran produk baru.

2. Rencana kegiatan pengembangan produk dari limbah produksi, meliputi;

1) Mengidentifikasi potensi reuse dan recycle dari limbah produksi elemen interior/furniture.

2) Memisahkan bahan hasil sisa produksi elemen interior/furniture berdasarkan sifatnya dan ukurannya.

3) Mendesain produk kreatif yang dapat dihasilkan dari limbah produksi, diutamakan produk kreatif yang berdaya jual.

4) Membuat produk kreatif berdasarkan konsep produk yang telah ditentukan sebelumnya.

3. Rencana kegiatan perluasan jaringan pemasaran, meliputi:

1) Mengidentifikasi jaringan pasar yang telah dimiliki oleh masing-masing mitra.

2) Mendokumentasi produk-produk interior dan produk kreatif lainnya sekaligus menyusun daftar harga masing masing produk.

3) Membuat katalog produk, menentukan harga produk serta mempromosikan produk, salah satunya melalui melalui media sosial.

\section{HASIL DAN PEMBAHASAN}

Hasil dari kegiatan pengabdian ini terlihat dari animo dan antusias pihak mitra, yakni CV Abstrak 3D dan CV Garis Pratama untuk turut berpartisipasi dalam kegiatan pengabdian dari awal hingga akhir. Selain berpartisipasi secara aktif, para mitra juga berpartisipasi dalam menyumbangkan ide-ide desain, menyediakan lokasi untuk pelatihan, menyediakan bahan limbah produksi, serta menyediakan tempat untuk pelatihan dan pembuatan produk.

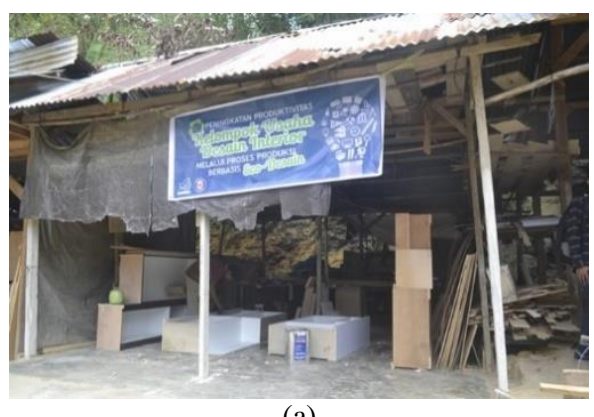

(a)

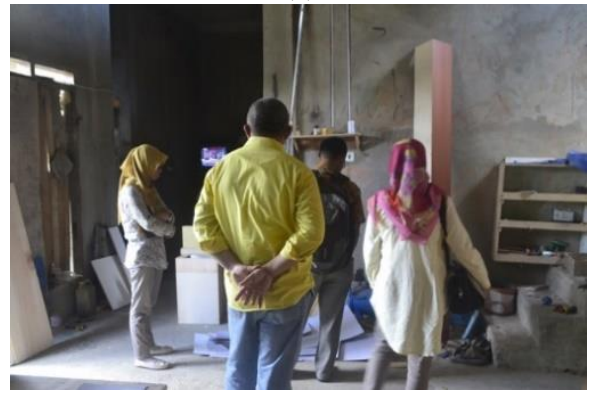

(b)

Gambar: bengkel kerja (a) CV Abstrak 3D

(b) CV Garis Pratama

Pelaksanaan FGD dilakukan di dua lokasi mitra pada waktu yang berbeda pula. Selain peserta dari kedua mitra, terdapat pula peserta yang berasal dari mahasiswa Pendidikan Vokasi UHO yang sedang memprogram mata kuliah Rekayasa Produk. Dengan keikutsertaan mahasiswa ini diharapkan akan menambah ilmu dan pengetahuan mahasiswa tentang berwirausaha desain interior yang baik, produktif dan dan tetap mengedepankan keberlangsungan lingkungan.

Seperti dikemukakan sebelumnya bahwa kegiatan pengabdian mengenai eco-design secara garis besar terdiri atas 3 tahap. Tahap pertama berupa kegiatan identifikasi potensi dan proses produksi serta pelaksanaan kegiatan 
FGD. Pada tahapan ini peserta diberi penyuluhan mengenai proses produksi berbasis eco-desain. Peserta juga diajak untuk mengamati bagaimana proses produksi furniture berjalan. Selanjutnya, peserta menganalisis dan menyesuaikan konsep ecodesain dan bagaimana cara menerapkannya ke dalam desain dan proses produksi.

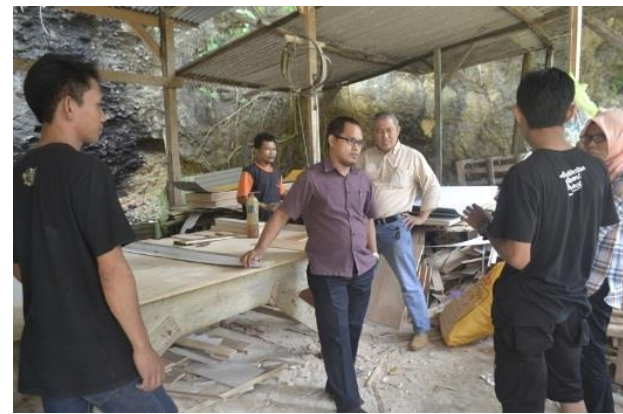

(a)

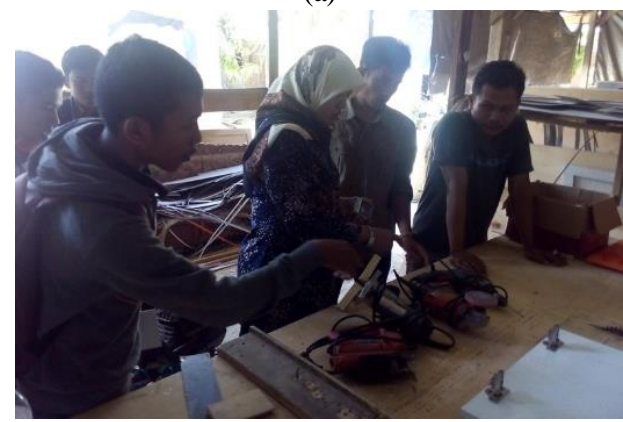

(b)

Gambar 3: Penjelasan (a) dan diskusi (b) antara tim pengabdian dengan peserta mengenai kegiatan produksi

Lingkup konsep eco-design tidak hanya seputar penanganan limbah saja, Akan tetapi merupakan proses dari awal hingga akhir. Beberapa contoh penerapan eco-design dalam industri desain interior dan furniture berskala kecil yakni sebagai berikut: meningkatkan keterampilan dasar para pekerja; pemilihan bahan baku yang ramah lingkungan; pemilihan bahan pelapis dan perekat yang tidak beracun (non VOC), memaksimalkan penggunaan peralatan masinal; penghematan energi listrik untuk bangsal kerja dan pada beberapa produk yang menggunakan lampu; serta menerapkan system Kesehatan dan Keselamatan Kerja (K3) dalam lingkungan kerja.

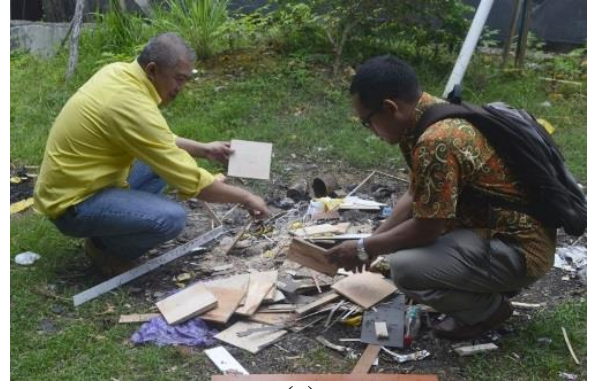

(a)

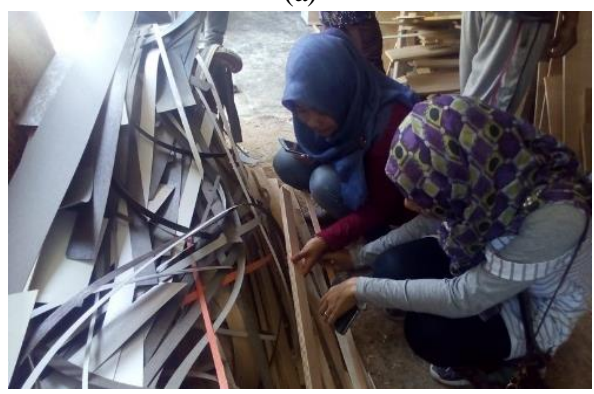

(b)

Gambar 4: (a) identifikasi potensi limbah (b) pengklasifikasian jenis dan dimensi limbah

Tahapan kedua yakni pengembangan produk dari limbah produksi. Kegiatan ini diawali dengan pengidentifikasian potensi limbah produksi elemen interior/furniture hingga pada tahapan pembuatan desain dan produksi produk kreatif yang dilakukan secara bersama-sama oleh pihak tim pengabdian, mitra serta mahasiswa. Berdasarkan hasil analisis, melalui pemanfaatan limbah ini, jumlah limbah kayu maupun pelapis dapat ditekan dari sekitar $20 \%$ hingga menjadi sekitar $7 \%$.

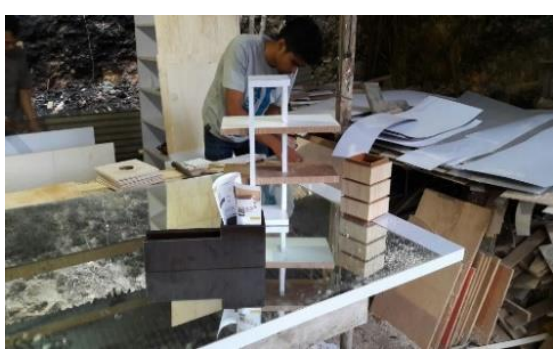

Gambar 5: Proses pembuatan produk dari limbah produksi

Tahapan ketiga, yakni kegiatan perluasan jaringan pemasaran. Pada umumnya, jenis usaha seperti kedua mitra tidak memiliki kapasitas produksi karena furniture hanya akan diproduksi sesuai dengan permintaan konsumen. Dengan adanya kegiatan ini, maka sistem pemasarannya perlu dikembangkan dengan langsung mempromosikan barang 
kepada konsumen. Salah satu caranya dengan membuat katalog/brosur, mengedarkannya langsung ke konsumen atau memanfaatkan jejaring sosial untuk memasarkan produk. Berdasarkan beberapa survey pasar terhadap berang-barang sejenis, maka harga produk dapat ditetapkan berkisar di Rp. 100.000,hingga Rp. 300.000,-, bergantung pada tingkat kerumitan produk.

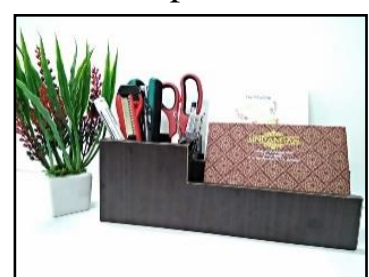

a.

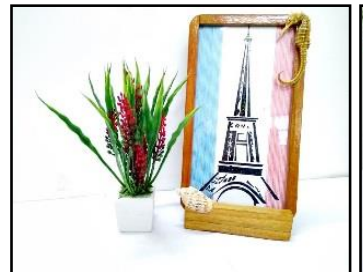

c.

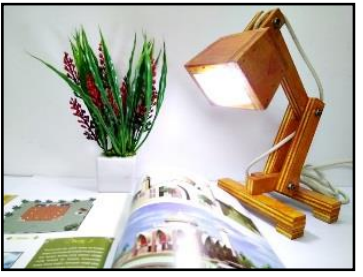

b.

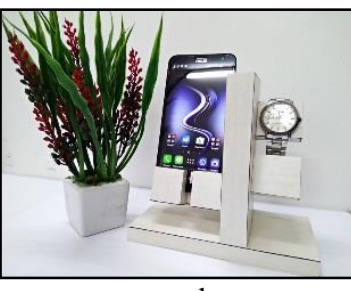

Gambar 6: beberapa produk pengabdian yang siap untuk dipasarkan (a) lampu belajar; (b) tempat alat tulis dan surat; (c) dudukan HP dan aksesoris; (d) bingkai foto
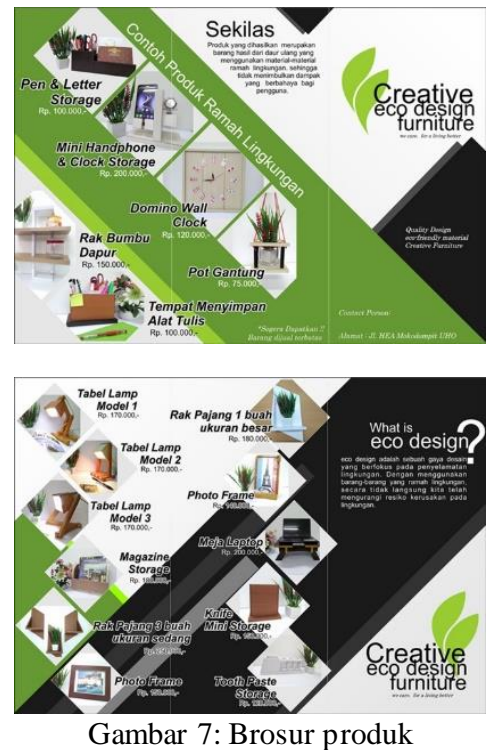

\section{KESIMPULAN DAN SARAN}

Kegiatan pengabdian yang dilaksanakan pada mitra CV Abstrak 3D dan CV Garis Pratama berjalan dengan baik. Melalui kegiatan ini, tim pengabdian memberikan tambahan pengetahuan kepada mitra mengenai proses produksi furniture/interior berbasis eco-design, dimulai dari pra produksi, produksi, hingga pada tahap pasca produksi. Pada tahap pasca produksi, pihak mitra diajak untuk mengolah limbah produksi sebaik mungkin dengan cara mengurangi volume sampah produksi untuk meningkatkan kapasitas produksi. Diharapkan dengan terlaksananya kegiatan ini mampu menumbuhkan kesadaran kelompok usaha kecil dan industry kreatif serupa untuk selalu mengedepankan unsur keberlanjutan lingkungan pada setiap proses produksinya.

Pada umumnya, kegiatan pengabdian dengan melibatkan mitra usaha adalah kegiatan yang bernilai positif, sehingga sebaiknya terus dijalin dan ditingkatkan cakupannya pada masa yang akan datang. Kerjasama antar pihak perguruan tinggi dan masyarakat umum, khususnya kelompok usaha kecil menengah diperlukan sebagai salah satu pengembangan prinsip tridharma perguruan tinggi.

\section{UCAPAN TERIMA KASIH}

Ucapan terima kasih penulis ditujukan kepada Rektor Universitas Halu Oleo, Ketua Lembaga Penelitian dan Pengabdian Pada Masyarakat, yang telah memberikan bantuan dana dan menyediakan fasilitas sehingga pengabdian ini dapat dilaksanakan. Selain itu pula, ucapan terima kasih kepada kedua mitra pengabdian, direktur dan segenap pekerja mitra CV Abstrak 3D dan CV Garis Pratama atas partisipasi dan bantuannya selama kegiatan pengabdian ini berlangsung.

\section{REFERENSI}

BPPT Kelompok Teknologi Pengelolaan Air Bersih dan Limbah Cair, 2012. Petunjuk Teknik Penanganan Limbah Lingkungan Hidup.

www.kelair.bppt.go.id/Publikasi/BukuPet nisLimbLH/06KAYU.pdf (sitasi 25 April 2015)

Ervianto, Wulfram I., 2012, Selamatkan Bumi Melalui Konstruksi Hijau, Penerbit Andi: Yogyakarta

Garcia, Juan Carlos and Eduardo Romeiro Filho, 2008, Ecodesign method for office furniture with emphasis on imformation gathering for product environmental improvement, Product: Management \& Development, Vol 6 June 2008. 39-44.

http://koperasimebel.com/macam-macamjenis-kayu-untuk-furniture/ diakses tanggal 25 April 2015 
http://adammurtaji.blogspot.com/proposalpengolahan-limbah-mebel diakses tanggal 25 April 2015)

http://kataloggeografi.blogspot.com/2014/01/in dustri-dan-dampaknya diakses tanggal 25 April 2015) 